\title{
Evidence for an Inhibitor of Insulin Release in the Pancreatic Islets*
}

\author{
B. Hellman and $\AA$. Lernmark \\ Histological Department, University of Umeå, Umeå, Sweden \\ Received May 6, 1968
}

Summary. The release of insulin in vitro from isolated mouse islets was significantly inhibited in the presence of an islet protein extract equivalent to more than 100 times the normal serum level of insulin. The nature of the inhibitory islet substance remains unclear. The possibility that the blood circulation through the islets may be important for the local regulation of insulin release by reducing high levels of this hormone in the immediate surroundings of the $\beta$ cells should be considered.

Pour preuve de l'existence d'un répresseur de la libération d'insuline dans les îlats pancréatiques

Résumé. La libération in vitro d'insuline par les îlots isolés de souris fut significativement réduite en présence d'un extrait de protéine îlotique contenant plus de 100 fois le taux normal d'insuline dans le sérum. La nature de la substance répressive d'origine insulaire reste obscure. La possibilité que la circulation de sang à travers les îlots puisse avoir de l'importance pour la régulation locale de la libération d'insuline en réduisant les taux élevés de cette hormone à proximité immédiate des cellules bêta doit être considérée.

Hinweise auf einen Hemmfaltor der Insulinfreisetzung in den Langerhans'schen Inseln

Zusammenfassung. Die Freisetzung von Insulin aus isolierten Mäuseinseln in vitro wurde in Gegenwart eines Proteinextraktes aus Langerhans'schen Inseln, das mehr als das Hundertfache der normalen Insulinmenge im Serum enthielt, merklich gehemmt. Die Natur dieses Hemmfaktors bleibt unklar. Man sollte die Möglichkeit besonders berücksichtigen, daß die Durchblutung der Inseln für die lokale Regelung der Insulinfreisetzung über eine Redultion der hohen Konzentration dieses Hormons in der unmittelbaren Umgebung der $\beta$-Zellen von Bedeutung sein kann.

Key-Words: Isolated pancreatic islets, insulin release in vitro, inhibitor of insulin release.
The pancreatic islets are well vascularized. It seems, however, hardly possible to interpret this morphological feature in terms of an excessive need for oxygen during the synthesis and secretion of insulin. As a matter of fact studies of the lactate dehydrogenase isoenzymes of the mouse islets revealed a pattern characteristic for a tissue with a low oxygen tension (Hgllmâ and TälJEdaL, 1967). Moreover, the endogenous respiratory rate of microdissected islets is lower than that of the liver and kidneys, and their oxygen uptake is not increased by more than $50 \%$ in the case of a maximal glucose-induced stimulation of insulin release (HELLERSTRöM, 1967).

A considerably enhanced rate of insulin secretion has recently been noted from isolated islets when the movements of the incubation fluid were increased by shaking (LERNMARK and HELLman, 1968). This observation raises the question whether the blood circulation may be important for the local regulation of insulin release by reducing high levels of this hormone in the immediate surroundings of the $\beta$ cells. In the present communication evidence is presented for a significant inhibition of insulin secretion after incubating isolated mouse islets with an islet protein extract equivalent to more than 100 times the normal serum level of insulin.

* Part of a project supported by the United States Public Health Service (AM-12535), Swedish Medical Research Council $(12 \mathrm{x}-562)$ and the Medical Faculty of Umeå.

\section{Materials and Methods}

Twelve adult male mice, representing the lean litter mates of obese-hyperglycaemic mice bred in our laboratory since 1959 (HeLlMAN, 1965), were starved for $18 \mathrm{~h}$ and killed by decapitation. In each experiment pieces of pancreas were removed from one animal and 8 islets carefully dissected under a stereomicroscope at $+2{ }^{\circ} \mathrm{C}$ as described by HeLlenström (1964). The islets were transferred to an equal number of polythene micro test tubes in such a way that the individual islet rested, surrounded by $15 \mu \mathrm{l} \mathrm{Krebs-Ringer} \mathrm{phosphate} \mathrm{buffer,}$ over a bottom bubble of air. The incubation medium was supplemented with glucose, $3 \mathrm{mg} / \mathrm{ml}$, and bovine serum albumin (Fraction $V$, Sigma Chemical Co.), $1 \mathrm{mg} /$ $\mathrm{ml}$. The composition of the incubation medium was adjusted to allow half the number of islets to be exposed to an islet protein extract. This protein extract was obtained by acetone precipitation of acid-ethanol extracted proteins from microdissected and homogenized pancreatic islets from starved, obese-hyperglycaemic mice. After incubation for $30 \mathrm{~min}$ at $37^{\circ} \mathrm{C}$ the islets were briefly washed, freeze-dried over night and weighed on a quartz fibre balance. The incubation media, as well as the freeze-dried and weighed islets, were assayed for insulin using the double antibody radioimmunological technique of HALES and RANDLE (1963). Each experiment also included parallel determinations of the amount of insulin before ( 2 test tubes) 
and after (2 test tubes) incubation of the islet protein extract in the absence of islets. Both the insulin antibodies and the 125I-insulin used in the radioimmunological insulin assay were supplied by the Radiochemical Centre, Amersham, England.

\section{Results}

The results have been summarized in Table 1. During incubation the amounts of insulin represented by the islet protein extract decreased by $15 \%$ to $32.2 \pm$ $2.1 \mathrm{ng} /$ incubation vessel. The latter amount is about

Table 1

\begin{tabular}{|c|c|c|}
\hline & $\begin{array}{l}\text { Medium with } \\
\text { added insulin }\end{array}$ & $\begin{array}{l}\text { Medium with- } \\
\text { out added in- } \\
\text { sulin }\end{array}$ \\
\hline $\begin{array}{l}\text { Insulin added initially } \\
\mathrm{ng} / \mathrm{vessel} \\
\mathrm{ng} / \mathrm{ml}\end{array}$ & $\begin{array}{c}38.1 \pm 3.6 \\
2539.2 \pm 246.6\end{array}$ & - \\
\hline $\begin{array}{l}\text { Recovery of added insulin } \\
\mathrm{ng} / \mathrm{vessel} \\
\mathrm{ng} / \mathrm{ml}\end{array}$ & $\begin{array}{c}32.2 \pm 2.1 \\
2148.6 \pm 144.2\end{array}$ & - \\
\hline $\begin{array}{l}\text { Insulin measured in the } \\
\text { presence of islets } \\
\mathrm{ng} / \mathrm{vessel} \\
\mathrm{ng} / \mathrm{ml}\end{array}$ & $\begin{array}{c}42.9 \pm 3.8 \\
2866.2 \pm 253.4\end{array}$ & $\begin{array}{c}18.3 \pm 3.3 \\
1214.4 \pm 216.6\end{array}$ \\
\hline $\begin{array}{l}\text { Mean islet weight } \\
\quad(\mu \mathrm{g}) \\
\text { Islet content of insulin }\end{array}$ & $0.90 \pm 0.08$ & $1.02 \pm 0.02$ \\
\hline $\begin{array}{l}\text { after incubation } \\
\text { ng/ug dry weight }\end{array}$ & $117.6 \pm 7.5$ & $114.5 \pm 9.2$ \\
\hline $\begin{array}{l}\text { Calculated insulin re- } \\
\text { lease } \\
\text { ng/ug islet dry weight } \\
\text { percentage of islet }\end{array}$ & $9.9 \pm 2.1$ & $19.1 \pm 3.0$ \\
\hline insulin & $7.7 \pm \mathbf{1 . 3}$ & $13.9 \pm 1.6$ \\
\hline
\end{tabular}

twice as much as was secreted when a single microdissected islet was incubated in the medium lacking the islet protein. Assuming that the recovery of insulin from the added islet protein was unaffected by the presence of a microdissected islet, the amounts of insulin released into the medium from the surviving islets were calculated as $9.9 \pm 2.1 \mathrm{ng} / \mu \mathrm{g}$ islet dry weight in the presence of islet protein compared with no less than $19.1 \pm 3.0$ for the controls $(t=2.51 ; P<0.025)$. The insulin release was also calculated in terms of the original islet content of this hormone, and found to be $7.7 \pm 1.3 \%$ in the presence of islet protein compared with $13.9 \pm 1.6 \%$ for the controls $(t=3.00 ; P<0.01)$. In the latter calculations the figures for the original islet content of insulin were obtained by adding together the amounts of insulin released and the amounts of insulin measured in the incubated islets.

\section{Discussion}

Previous studies have shown that insulin constitutes $14 \%$ of the dry weight of the $\beta$ cells in the rat (LACY, 1962; DIXIT et al., 1962). The present observa- tion of an insulin content of no less than $12-13 \%$ in the islets from lean mice means that their $\beta$ cells contain somewhat more insulin per unit weight than is found in the rat. Furthermore, the amounts of insulin released from the mouse islets, when incubated in the absence of islet extract, were considerably higher than those noted for rat islets isolated with the collagenase technique. As a matter of fact, MalaIsse et al. (1968) have reported that the amounts of insulin released over $60 \mathrm{~min}$ did not exceed $5 \%$ of the stored hormone. Our limited experience with the collagenase technique does not justify any conclusions concerning to what extent the different procedures of isolating the islets might have contributed to the discrepancies recorded. Although the direct dissection of islets weighing only about $1 \mu \mathrm{g}$ undoubtedly involves less gentle mechanical handling than is possible with the considerably larger islets in the obese-hyperglycaemic mice, it should be borne in mind that the collagenase technique involves prolonged exposure of the islets to a rather strong enzyme solution at $37^{\circ} \mathrm{C}$.

When evaluating the present data, attention should be paid to the fact that the added islet extract also contains components other than insulin. Besides a major content of non-insulin proteins, minor amounts of phospholipids and nucleic acids can be expected to be included in the acetone precipitate. The figures obtained in the insulin assay were used for a rough estimation of the total amount of protein in the islet extract, assuming that the islets from starved, obesehyperglycaemic mice contain $90 \% \quad \beta$ cells, with an average insulin content corresponding to $20 \%$ of their proteins (HellMaN, 1965; LERNMARK et al., 1968). Such a calculation revealed that the added amounts of protein corresponded to only about $1 \%$ of the original protein in the incubation medium.

The fact that our islet extract was prepared from the enlarged islets of obese-hyperglycaemic mice means that it was prepared essentially from $\beta$ cells. If the small amounts of $\alpha_{2}$ cells interfered with $\beta$ cell function, this might rather be expected to have increased the insulin release in view of their content of glucagon (SAmols et al., 1966; Coone et al., 1967). There is some evidence to suggest that the $\alpha_{1}$ cells produce gastrin (Cavaluero and Solcta, 1965). If they indeed secrete this hormone, the amounts of added islet proteins might very well be enough to reach a final concentration of $0.15 \mu \mathrm{g} / \mathrm{ml}$. The latter concentration has recently been found to inhibit insulin release from isolated mouse islets in the presence of glucose (LERNMARK et al., 1968). It is also possible that the $\beta$ cells themselves might contain a specific but still unknown inhibitor of insulin release. GRoDsky et al. (1967) reported prompt insulin release (phase 1) followed by a rapid fall to a comparatively steady level (phase 2), when perfusing an isolated rat pancreas preparation with glucose. The biphasic nature of the insulin response was attributed to an intracellular feedback inhibitor not identical with insulin. 
Freriohs et al. (1965) have presented some evidence for inhibition of insulin release from the isolated rat pancreas when insulin was added to the incubation medium. These results have been criticized by MALAISSE et al. (1967), who stated that neither insulin nor guinea pig anti-insulin serum had a direct effect on insulin secretion from isolated rat islets. The data presented by MALAISSE et al. (1967) can be used as a strong argument against the existence of a feedback regulation of insulin secretion mediated by the insulin level in the blood entering the islets. The present study suggests the more plausible alternative that the blood circulation through the islets affects insulin release by reducing the very high levels of this hormone in the immediate surroundings of the $\beta$ cells. As a matter of fact, the insulin concentration provided by our islet extract was about 50 times higher than that used by MALAISSE et al. (1967) and more than 100 times higher than that found in serum in this strain of mice (WESTMAT, 1968). Before any conclusions can be drawn as to whether the observed inhibition of insulin release can be attributed to the insulin in the islet extract, the same concentrations of this hormone should be tested in a pure crystalline form.

\section{References}

Cavallero, C., and E. Solcta: Cytological and cytochemical aspects of islet pathology in the Zollinger-Ellison syndrome. Rev. int. Hepat. 15, 517-526 (1965).

Coore, H. G., B. Helmman, L. A. IdAHL, and I. B. TäLJEDAL: Diabetes research at the Histological department in Umeå. Opusc. Med. 12, 285-295 (1967).

Dixit, P.K., I. Lowe, and A. Lazarow: Effect of alloxan on the insulin content of micro-dissected mammalian pancreatic islets. Nature (Lond.) 195, 388-389 (1962).

Frerichs, H., U. Reich, and W. CreutzFeldt: Insulinsekretion in vitro. Klin. Wschr. 43, 136-140 (1965).
Grodsky, G.M., L.L. Bennetr, D. SMrth, and K. NEMECHEK: The effect of tolbutamide and glucose on the timed release of insulin from the isolated perfused pancreas. In BUTTERFIELD, W.J.H., and W. van WESTERING (editors): Tolbutamide after Ten Years. Excerpta med. Foundation, p. 11-21 (1967).

HaLES, C.N., and P.J. RANDLE: Immunoassay of insulin with insulin-antibody precipitate. Biochem. J. 88, 137 -146 (1963).

Hellerström, C.: A method for the microdissection of intact pancreatic islets of mammals. Acta endocr. (Kbh.) 45, 122-132 (1964).

- Effects of carbohydrates on the oxygen consumption of isolated pancreatic islets of mice. Endocrinology 81, $105-112$ (1967).

Hellman, B.: Studies in obese-hyperglycemic mice. Ann. N. Y. Acad. Sci. 131, $541-558$ (1965).

- and I.B. TÄL.JEDAL: Quantitative studies on isolated pancreatic islets of mammals. Activity and heterogeneity of lactate dehydrogenase in obese-hyperglycemic mice. Endocrinology 81, 125-131 (1967).

LACY, P.E., and J.R. WILliamsson: Quantitative histochemistry of the islets of Langerhans. Diabetes 11, 101 -104 (1962).

Lernmark, $\AA$, and B. Hellman: Unpublished observations (1968).

- B. Hellman, and H.G. Coore: Effects of gastrin on the in vitro release of insulin. J. Endocrinol in press (1968).

Malatsse, W.J., F. Malatssf-Lagat, and S. King: Quantitative and qualitative aspects of islet function in the rat. J. Lab. clin. Med. 71, 56-64 (1968).

- - P.E. LACY, and P.H. WRIGHT: Insulin secretion by isolated islets in presence of glucose, insulin, and antiinsulin serum. Proc. Soc. exp. Biol. (N.Y.) 124, 497500 (1967).

SAMols, E., G. MarRI, and V. Marks: Interrelationship of glucagon, insulin and glucose. The insulinogenic effect of glucagon. Diabetes 15, 855 - 866 (1966).

WeStman, S.: Development of the obese-hyperglycemic syndrome in mico. Diabetologia 4, 141-149 (1968).

Bo. Hellman, M.D.

Histological Department

University of Umeå

Umeå, Sweden 